\title{
Spontaneous Expectoration of Tumor Tissue in a Patient With Adenocarcinoma of the Lung
}

\author{
Nobuaki Ochi MD, Masayuki Yasugi MD, Hiromichi Yamane MD PhD, \\ Takayuki Tabayashi MD PhD, Norikuni Kawanaka MD PhD, Niro Okimoto MD PhD, \\ Yasumasa Monobe MD PhD, and Nagio Takigawa MD PhD
}

\section{Introduction}

Expectoration of tumor tissue is a rare presentation in patients with cancer. Thirty cases of various types of tumor, including primary or metastatic lung cancer, have been reported. Endobronchial metastases from various organs are most common, although 9 primary lung cancer cases have been described, including 4 squamous cell carcinomas, 2 bronchogenic carcinoids, one small cell lung carcinoma, one large cell carcinoma, and one mixed type carcinoma. ${ }^{1-9}$ Adenocarcinoma of the lung has never been reported. We describe a case of spontaneous expectoration of a piece of lung adenocarcinoma, which enabled a definitive diagnosis of a local recurrence, and led to substantial relief from dyspnea.

\section{Case Summary}

A 56-year-old man with a 30-pack-year smoking history presented with respiratory distress. Recurrence of lung cancer was suspected because he had undergone a left upper lobectomy for lung adenocarcinoma (pT1N0M0, stage IA) 18 months earlier. The physical examination revealed no breath sounds on the left side. Bronchoscopy revealed protrusion of a tumor into the trachea from the left main bronchus (Fig. 1A); however, the biopsy specimen yielded

\footnotetext{
The authors are affiliated with the Department of General Internal Medicine 4, Kawasaki Hospital, Kawasaki Medical School, Okayama, Japan; with the exception of Drs Kawanaka and Okimoto, who are affiliated with the Department of General Internal Medicine 1, and Dr Monobe, who is affiliated with the Department of Pathology at that institution.

The authors have disclosed no conflicts of interest.

Correspondence: Nagio Takigawa MD PhD, Department of General Internal Medicine 4, Kawasaki Hospital, Kawasaki Medical School, 2-180, Nakasange, Kita-ku, Okayama, 700-8505, Japan. E-mail: ntakigaw@ med.kawasaki-m.ac.jp.
}

DOI: $10.4187 /$ respcare.01626 only necrotic tissue. Two weeks after bronchofiberscopy he was confined to bed due to severe dyspnea and a forceful productive cough. When he presented to our department, stridor was heard in the anterior neck region, and chest computed tomography revealed a huge mass on the left hilum obstructing the left main bronchus and constricting the trachea (Fig. 2A and 2B). $\mathrm{S}_{\mathrm{pO}_{2}}$ was $85 \%$ on room air, and the $\mathrm{S}_{\mathrm{pO}_{2}}$ increased to $95 \%$ while receiving oxygen at $5 \mathrm{~L} / \mathrm{min}$ via an oxygen mask with a reservoir bag. When he had a paroxysmal cough, he expectorated tumor tissue $(18 \times 20 \times 5 \mathrm{~mm}$, see Fig. 1B) with some bloody sputum. This relieved his dyspnea and forceful cough. The expectorated tumor specimen was pathologically compatible with a recurrence of the previously resected lung adenocarcinoma (see Fig. 1C and D). The stenosis of the trachea was improved on chest computed tomography (see Fig. $2 \mathrm{C}$ and D).

\section{Discussion}

Tumor expectoration is a rare presentation in patients with various tumors. Since Walshe et al described expectorated tumor fragments in sputum in $1843,{ }^{1} 30$ cases have been reported (Table). The most frequent tumor was renal cell carcinoma ( 8 cases, 26.7\%), ${ }^{10-13,15}$ followed by primary lung cancer and sarcoma (7 cases each, $23.3 \%$ each). ${ }^{1-4,6-8,16-21}$ Twenty-four cases $(80.0 \%)$ were observed in men. Tumor expectoration occurred at either the initial presentation $(36.7 \%)$ or at the time of recurrence (46.7\%). It was observed immediately after bronchofiberscopy $3,7,26$ in 3 cases, while it occurred spontaneously in the other cases.

Tumors showing endobronchial growth are prone to exfoliate into the airway. ${ }^{9,16,17,21}$ As seen in our case, tumor expectoration might lead to pathological information and could relieve the respiratory symptoms. Histologically, adenocarcinoma accounts for a large proportion of cases in non-small-cell lung cancer worldwide; however, there has been no report of tumor expectoration in a patient with 


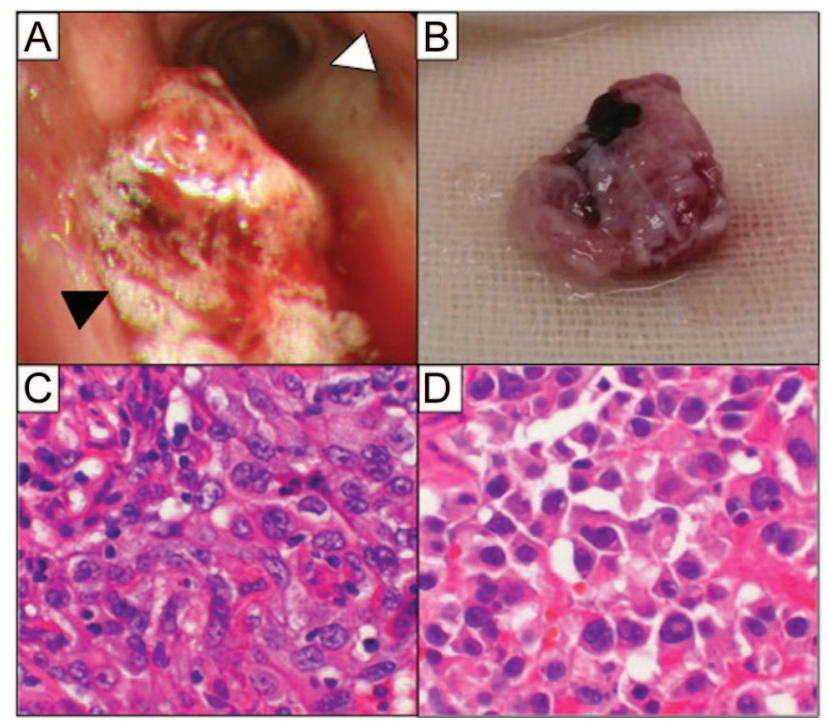

Fig. 1. Bronchoscopy revealed protrusion of the tumor into the trachea from the left main bronchus (A). Black-and-white arrowheads indicate the inlet of the left main bronchus obstructed by the tumor and the right main bronchus, respectively. The macroscopic finding of the expectorated tumor tissue (B). The pathological findings of the resected primary tumor $(C)$ and expectorated tumor tissue (D). Adenocarcinoma cells were found in both specimens.

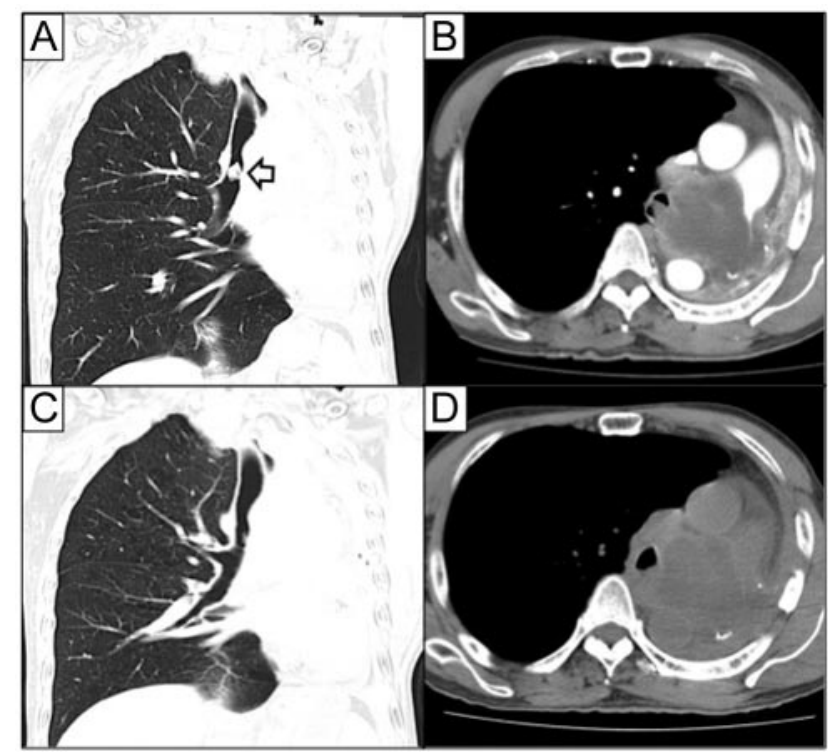

Fig. 2. Computed tomography showed a huge mass on the left hilum, obstructing the left main bronchus and constricting the trachea ( $A$ and $B)$. The arrow indicates the airway obstruction caused by the tumor growing into the trachea. The stenosis of the trachea improved after the tumor tissue was expectorated (C and $D)$.

Table. Characteristics of Cases of Tumor Expectoration

\begin{tabular}{|c|c|c|c|c|c|c|}
\hline First Author & Sex & Age (y) & Tumor Type & Suplaclavicular fossa & Primary or Not & Size $(\mathrm{cm})$ \\
\hline Maytum $^{10}$ & $\mathrm{M}$ & 63 & Renal cell cancer & Kidney & ND & 1.0 \\
\hline Seiler ${ }^{11}$ & $\mathrm{~F}$ & 39 & Renal cell cancer & Kidney & Recurrence & ND \\
\hline Gerle $^{12}$ & M & 51 & Renal cell cancer & Kidney & Primary & 1.0 \\
\hline Jariwalla $^{13}$ & M & 34 & Renal cell cancer & Kidney & Recurrence & 1.0 \\
\hline Jariwalla $^{13}$ & M & 61 & Renal cell cancer & Kidney & Recurrence & $<5.0$ \\
\hline Jariwalla $^{13}$ & M & 43 & Renal cell cancer & Kidney & Recurrence & $2.0 \times 2.0$ \\
\hline Eissler $^{14}$ & $\mathrm{~F}$ & 42 & Renal cell cancer & Kidney & ND & ND \\
\hline Daryanani ${ }^{15}$ & M & 55 & Renal cell cancer & Kidney & Recurrence & $4.0 \times 2.0$ \\
\hline Dixit $^{7}$ & $\mathrm{M}$ & 60 & Lung (large cell) & Lung & Primary & $1.2 \times 1.1$ \\
\hline $\mathrm{Kern}^{4}$ & M & 68 & Lung (mixed) & Lung & Primary & $2.5 \times 0.6 \times 1.5$ \\
\hline Kaira $^{8}$ & M & 77 & Lung (small) & Lung & Recurrence & $3.0 \times 2.5 \times 1.0$ \\
\hline D'hour ${ }^{6}$ & M & 58 & Lung (squamous) & Lung & ND & ND \\
\hline Mital $^{1}$ & M & 55 & Lung (squamous) & Lung & Primary & $3.0 \times 2.0$ \\
\hline Goldstein $^{2}$ & M & 78 & Lung (squamous) & Lung & Primary & $2.0 \times 1.0 \times 0.5$ \\
\hline Wigton $^{3}$ & $\mathrm{M}$ & 51 & Lung (squamous) & Lung & Primary & Almond size \\
\hline Curry ${ }^{16}$ & $\mathrm{~F}$ & 12 & Sarcoma & Bronchus & Primary & $1.5 \times 1.0$ \\
\hline $\operatorname{Lee}^{17}$ & M & 59 & Sarcoma & Bronchus & Primary & $1.0 \times 1.0 \times 2.0$ \\
\hline Clark $^{18}$ & M & 44 & Sarcoma & Suplaclavicular fossa & Recurrence & ND \\
\hline Sharma ${ }^{19}$ & M & 57 & Sarcoma & Right foot & Recurrence & 5.0 \\
\hline Brade $^{20}$ & $\mathrm{M}$ & 42 & Sarcoma & Right patellar tendon & Recurrence & $2.5 \times 1.0$ \\
\hline Wigton $^{3}$ & ND & ND & Sarcoma & ND & ND & ND \\
\hline Watanabe ${ }^{21}$ & M & 34 & Sarcoma & Bronchus & Primary & $7.5 \times 2.0 \times 1.5$ \\
\hline Rubin $^{22}$ & ND & 61 & Colon cancer & Colon & ND & ND \\
\hline Zias $^{23}$ & $M$ & 75 & Colon cancer & Colon & Recurrence & ND \\
\hline Ghetie $^{24}$ & M & 75 & Colon cancer & Colon & Recurrence & $2.3 \times 1.2 \times 1.7$ \\
\hline Gómez ${ }^{25}$ & M & 43 & Colon cancer (rectal) & Colon & Recurrence & 4.0 \\
\hline Córdoba $^{5}$ & M & 71 & Carcinoid & Bronchus & Primary & 1.0 \\
\hline Kelly ${ }^{9}$ & $M$ & 25 & Carcinoid & Bronchus & Primary & $1.8 \times 0.6 \times 0.5$ \\
\hline Sutton ${ }^{26}$ & M & 25 & Melanoma & Left pectoral area & Recurrence & $1.5 \times 2.0$ \\
\hline Sutton ${ }^{26}$ & $\mathrm{~F}$ & 26 & Melanoma & Left forearm & Recurrence & Cupful \\
\hline
\end{tabular}

$\mathrm{ND}=$ not described 


\section{Spontaneous Expectoration of Tumor Tissue in a Patient With Adenocarcinoma}

adenocarcinoma of the lung. One explanation for the phenomenon may be the characteristics of the disease: the primary site is usually located in the peripheral lung and would be unlikely to involve a central airway, leading to tumor expectoration. Conversely, squamous cell carcinoma of the lung often involves central lesions.

In conclusion, we experienced spontaneous expectoration of a piece of lung adenocarcinoma. Kelly et al stated that physicians might ignore such specimens, presuming them to be phlegm or blood clots. ${ }^{9}$ We should be aware that the expectorated tissue might lead to a pathological diagnosis, even in adenocarcinoma of the lung.

\section{Teaching Points}

Tumor expectoration is a rare presentation in patients with various tumors. To date, 30 cases have been reported. The most frequent tumor was renal cell carcinoma, followed by primary lung cancer and sarcoma. The patient's spontaneously expectorated material should not be discarded, and should be fixed and examined by a pathologist, since it can provide diagnostic information.

\section{REFERENCES}

1. Mital OP, Agarwala MC. Expectoration of a bronchogenic carcinoma. Br J Dis Chest 1968;62(1):52-53.

2. Goldstein AR. Expectoration of bronchogenic tumor tissue. JAMA 1976;236(11):1271

3. Wigton R, Rohatgi PK. Expectoration of bronchogenic carcinoma. J Natl Med Assoc 1978;70(11):799.

4. Kern WH. Expectoration of bronchogenic tumor tissue. JAMA 1976; 236(23):2604.

5. Córdoba A, de Llano P, Arrechea MA, Beloqui R, Gómez ML. Partial expectoration of a typical carcinoid: report of a case with diagnosis on sputum cytology. Acta Cytol 2006;50(5):581-583.

6. D'hour H, Toison J, Cabotse J. Opacity of the right superior lobe of the lung; spontaneous expectoration of a tumor fragment. J Sci Med Lille 1954;72(2):73-77. Article in French.

7. Dixit R, Joshi N, Nuwal P, Purohit SD, Gupta RC, Gupta N. Postbronchoscopy expectoration of tumour tissue in lung cancer. Indian J Chest Dis Allied Sci 1999;41(2):105-109.
8. Kaira K, Shimizu Y, Sunaga N, Hisada T, Ishizuka T, Mori M. Expectoration of bronchogenic tumour tissue. Intern Med J 2007; 37(5):340-342.

9. Kelly WF, Crawley EA, Vick DJ, Hurwitz KM. Spontaneous partial expectoration of an endobronchial carcinoid. Chest 1999;115(2):595598

10. Maytum CK, Vinson PP. Pulmonary metastasis from hypernephroma, with ulceration into a bronchus simulating primary bronchial carcinoma. Arch Otolaryngol 1936;23(1):101-104.

11. Seiler HH, Clagett OT, McDonald JR. Pulmonary resection for metastatic malignant lesions. J Thorac Surg 1950;19(5):655-679.

12. Gerle R, Felson B. Metastatic endobronchial hypernephroma. Dis Chest 1963;44:225-233

13. Jariwalla AG, Seaton A, McCormack RJ, Gibbs A, Campbell IA, Davies BH. Intrabronchial metastases from renal carcinoma with recurrent tumour expectoration. Thorax 1981;36(3):179-182.

14. Eissler M. Spontaneous regression of lung metastasis in renal cell carcinoma with expectoration of a part of the metastasis. Med Klin (Munich) 1989;84(2):118-119. Article in German.

15. Daryanani S, Knausenberger HP, de Takats PG, Guest PJ, Kerr DJ. Spontaneous pneumothorax associated with expectoration of a lump of metastatic renal cancer. Clin Oncol 1997;9(4):262-263.

16. Curry JJ, Fuchs JE. Expectoration of a fibrosarcoma; patient well 4 years later. J Thorac Surg 1950;19(1):135-137.

17. Lee SH, Shim JJ, Shin JS, Baek MJ, Choi YH, Kim MK, et al Primary endobronchial leiomyosarcoma. Diagnosis following expectoration of tumor fragment. Respiration 2001;68(1):99-102.

18. Clark MA, Hayes AJ, Thomas JM. Expectoration of endobronchial sarcoma metastasis. ANZ J Surg 2004;74(10):913-914

19. Sharma KB. Spontaneous expectoration of lung tumour mass. CMAJ 2005;172(9):1182.

20. Brade A, O'Sullivan B, Cummings B, Quirt I. A positive prognosis. CMAJ 2005;173(10):1206.

21. Watanabe R, Kamiyoshihara M, Kaira K, Motegi A, Takise A. Spontaneous expectoration of primary pulmonary synovial sarcoma. J Thorac Oncol 2006;1(9):1025-1026.

22. Rubin E. The lung as a mirror of systemic disease. Springfield: Charles C. Thomas; 1956:283-284.

23. Zias EA, Owen RP, Borczuk A, Reichel J, Frater RW. An unusual presentation of metastatic colon cancer to the lung. Chest 1998; 113(1):244-246.

24. Ghetie C, Davies M, Cornfeld D, Suh N, Saif MW. Expectoration of a lung metastasis in a patient with colorectal carcinoma. Clin Colorectal Cancer 2008;7(4):283-286.

25. Gómez Heras L, Sanz Rubiales A, del Valle Rivero ML, Uña Cidón E, Hernansanz de la Calle S. Spontaneous expectoration of a tumour fragment. An Med Interna 2005;22(10):501. Article in Spanish.

26. Sutton FD Jr., Vestal RE, Creagh CE. Varied presentations of metastatic pulmonary melanoma. Chest 1974;65(4):415-419. 